\title{
REDUCED DOSES OF A SULFONYLUREA HERBICIDE FOR WEED MANAGEMENT IN WHEAT FIELDS OF PUNJAB, PAKISTAN
}

\author{
Abdul Khaliq ${ }^{1 *}$, Amar Matloob ${ }^{1}$, Asif Tanveer ${ }^{1}$, Ahsan Areeb ${ }^{1}$, Farhena Aslam¹, and Nadeem Abbas ${ }^{1}$
}

Reduction in herbicide usage without compromising yields can lead to less environmental harm and lower production costs. Field trials were conducted to appraise the efficacy of reduced doses $(25,50$, and $75 \%$ of the label dose) of a post emergence sulfonylurea herbicide [Atlantis 3.6WG (iodo+mesosulfuron)] to control weeds in wheat (Triticum aestivum L.) fields of Punjab, Pakistan. Below-labeled-doses were quite effective in suppressing total weed density (72-95\%) and biomass (83$94 \%$ ), and wheat grain yield was increased by 22 to $48 \%$ over the weedy control, while label dose of iodo+mesosulfuron improved yield by 53\%. Iodo+mesosulfuron at 25 and $50 \%$ of the label dose inhibited grass weeds by 43 to $64 \%$, albeit their biomass was suppressed by $>80 \%$ over control. Wheat yields for reduced herbicide doses ( 50 and $75 \%$ ) were not different with label dose. Economic analysis revealed that the maximum marginal rate of return was recorded for $50 \%$ of the label herbicide dose and was followed by that observed for $25 \%$ of the label dose. Reduced doses of herbicide can be an effective tool in minimizing herbicide inputs and lowering production costs in wheat production without compromising yields.

Key words: Reduced herbicide dose, weed suppression, efficiency, wheat yield.

A mongst various factors adversely influencing crop productivity, weed infestation in crop lands remains the most devastating one. Weeds are the most omnipresent class of pests that interfere with crop plants through competition and allelopathy, resulting in direct loss to quantity and quality of the product (Gupta, 2004), and indirectly increasing production costs. A mix stand of grassy and broad-leaved weeds is reported to cause $48 \%$ yield loss of wheat (Triticum aestivum L.) in Pakistan (Khan and Haq, 2002). Numerous approaches have been in practice for handling the problem of weed infestation. Chemical weed control seems indispensable and has proved efficient in controlling weeds (Kahramanoglu and Uygur, 2010), and hence currently about two-third, by volume, of the pesticides used worldwide in agricultural production are herbicides. In Pakistan, herbicide usage accounts for $14 \%$ of the total pesticide consumption (Khan, 1998). Out of total imports of herbicides into the country (amounting to 36.6 million US\$), 63\% were used on wheat (Ashiq et al., 2006). Indiscriminate use of herbicides for weed control during the past few decades has resulted in serious ecological and environmental problems, such as resistance, shifts in weed populations that are more closely related to the crops that they infest, minor weeds becoming dominant (Heap, 2007), and greater environmental and health hazards (Rao, 2000). Sky rocketing input prices, crop injury and reduced profits are issues that need to be solved through reduction in pesticide usage.

${ }^{1}$ University of Agriculture, Department of Agronomy, Faisalabad 38040, Pakistan. "Corresponding author (khaliquaf@gmail.com).

Received: 13 January 2011.

Accepted: 27 April 2011.
The efficacy of any herbicide depends predominately on the dose used (Steckel et al., 1997) and in many instances the same is also decisive for its selectivity. Registered herbicide doses are set to achieve upper limits of weed control under varying compositions, densities, weed growth stages and environmental conditions, and there may be an overestimation of the dose required to get adequate control (Zhang et al., 2000). To ensure satisfactory weed control, even under unfavorable regimes of crop production factors, manufacturers often recommended higher than necessary doses of an herbicide. However, it is not always necessarily to apply full herbicide dose (Talgre et al., 2008) and there can flexibility regarding herbicide rates depending on the weed spectrum, densities, their growth stage and environmental conditions of the site. Moreover, modern weed science also emphasizes following an ecological approach based on keeping weed populations below threshold levels rather than eradicating them (Barroso et al., 2009). Numerous herbicide molecules at lowerthan-recommended rates are effective enough to provide satisfactory weed control without sacrificing yields and increasing weed infestation in the following years (Zhang et al., 2000; Boström and Fogelfors, 2002; Walker et al., 2002; Auskalnis and Kadzys, 2006; Barros et al., 2007). Reduced herbicide doses seem to offer a promising tool for decreasing herbicide usage across the globe.

Weed species also tend to vary in their susceptibility to different doses of a specific herbicide. Zhang et al. (2000) reviewed use of reduced herbicide doses and concluded that weed control efficiency tends to be lower and more erratic at reduced doses than at recommended doses, although it was commercially acceptable (60-100\%) in most cases. 
Wild oat (Avena fatua L.) biomass was $20-400 \%$ greater when herbicide was used at half the recommended rate, but this biomass increase was ineffective regarding yield and net return (Barton et al., 1992; Holm et al., 2000). Belles et al. (2000) reported $>85 \%$ and consistent control of wild oat with a half-dose of tralkoxydim. Atlantis $3.6 \mathrm{WG}$ (iodo+mesosulfuron) is a commonly used broad spectrum herbicide of the sulfonylurea group registered for wheat in Pakistan. A previous work of Barros et al. (2005; 2007) showed a fair degree of success with this herbicide even at reduced rates, but results are restricted to Mediterranean conditions. The present study was designed to evaluate the extent of weed suppression by reduced herbicide doses of iodo+mesosulfuron under the semi-arid conditions of Punjab, Pakistan.

\section{MATERIALS AND METHODS}

\section{Site and crop husbandry}

Field experiments were conducted at the Agronomic Research Farm, University of Agriculture, Faisalabad $\left(31.5^{\circ} \mathrm{N}, 73.09^{\circ} \mathrm{E}\right)$, Pakistan, during winters of 2008 2009 and 2009-2010 to evaluate the weed suppressive activity of iodo+mesosulfuron (4-iodo-2-[(4-methoxy6-methyl-1,3,5-triazin-2-yl) carbamoylsulfamoyl] benzoic acid + methyl 2-[(4,6-dimethoxypyrimidin-2ylcarbamoyl) sulfamoyl]-a-(methanesulfonamido)-ptoluate) applied at reduced rates in wheat. Experiments were laid out in a randomized complete block design (RCBD) with four replicates. The net plot size was $6 \mathrm{~m} \times$ $2.20 \mathrm{~m}$. Soil samples were collected before crop sowing to a depth of $15 \mathrm{~cm}$ and analyzed for various physicochemical properties (Table 1). Wheat cv. Shafaq-2006 was planted in the first fortnight of November 2008 and 2009 with a single row hand drill, using a seed rate of $125 \mathrm{~kg} \mathrm{ha}^{-1}$ and maintaining $20 \mathrm{~cm}$ distance between crop rows. A basal fertilizer dose of $125 \mathrm{~kg} \mathrm{~N}, 75 \mathrm{~kg} \mathrm{P}_{2} \mathrm{O}_{5}$, and $60 \mathrm{~kg} \mathrm{~K}_{2} \mathrm{O}$ ha $^{-1}$ was applied in the form of urea $(46 \% \mathrm{~N})$, diammonium phosphate $\left(18 \% \mathrm{~N} ; 46 \% \mathrm{P}_{2} \mathrm{O}_{5}\right)$ and sulfate of potash $\left(50 \% \mathrm{~K}_{2} \mathrm{O}\right)$. The whole $\mathrm{P}$ and $\mathrm{K}$ and half of $\mathrm{N}$ were applied at sowing. The remaining half of $\mathrm{N}$ was top dressed with the second irrigation at the booting stage. Besides soaking irrigation, four irrigations were applied to produce the wheat crop.

\section{Treatment application}

Four doses of iodosulfuron methyl sodium (0.6\%) +

Table 1. Physicochemical properties of soil used for field experiment.

\begin{tabular}{lclll}
\hline \multicolumn{2}{c}{ Physical } & & \multicolumn{2}{c}{ Chemical } \\
\cline { 1 - 2 } \cline { 5 - 5 } Characteristics & Value & & \multicolumn{1}{c}{ Characteristics } & Value \\
\hline Sand, \% & 48.20 & & Total soluble salts, $\mathrm{d} \mathrm{Sm}^{-1}$ & 1.2 \\
Silt, \% & 23.47 & & pH & 7.6 \\
Clay, \% & 28.33 & & Organic matter, $\%$ & 0.71 \\
Textural class & Sandy clay loam & & Total N, \% & 0.062 \\
& & & Available P, $\mathrm{mg} \mathrm{kg}^{-1}$ & 13.1 \\
& & Available K, $\mathrm{mg} \mathrm{kg}^{-1}$ & 179 \\
\hline
\end{tabular}

mesosulfuron-methyl (3\%) [Atlantis 3.6WG, Bayer Crop Science, Karachi, Pakistan] at 3.6, 7.2, 10.8, and $14.4 \mathrm{~g}$ ai $\mathrm{ha}^{-1}(25,50,75$ and $100 \%$ of the label dose, respectively) were used. The post-emergence foliar application was done with a Knapsack hand sprayer fitted with a T-Jet nozzle and at a pressure of $207 \mathrm{kPa}$ at $30 \mathrm{~d}$ after sowing (DAS) when the crop was at the jointing stage. A weedy control was maintained for comparison. Spray volume (300 $\mathrm{L} \mathrm{ha}^{-1}$ ) was determined by calibration using water.

\section{Harvesting and data collection}

Data on weed dynamics (density, dry weight) were recorded at 45 and 75 DAS from two randomly selected quadrants $(50 \times 50 \mathrm{~cm})$ from each experimental unit. Weeds were counted individually and clipped at ground level to record their biomass. Weed dry weight was recorded after drying in an oven at $70{ }^{\circ} \mathrm{C}$ for $48 \mathrm{~h}$. This data were further used to compute different indices as proposed by Walia (2003):

Weed persistence index (WPI):

$$
\mathrm{WPI}=\frac{\begin{array}{c}
\text { Dry matter of weeds } \\
\text { in treated plots }
\end{array}}{\begin{array}{c}
\text { Dry matter of weeds } \\
\text { in control }
\end{array}} \times \frac{\begin{array}{c}
\text { Weed count in } \\
\text { control }
\end{array}}{\begin{array}{c}
\text { Weed count in } \\
\text { treated plots }
\end{array}}
$$

Herbicide efficiency index (HEI):

$$
\mathrm{HEI}=\frac{\mathrm{YT}-\mathrm{YC}}{\mathrm{YC}} \times 100 / \frac{\mathrm{DMT}}{\mathrm{DMC}} \times 100
$$

where YT and YC stand for the yields of treated and weedy control, respectively, while DMT and DMC refer to respective weed dry matter. The WPI and HEI denote the tolerance of weeds to a particular treatment and efficiency of various herbicide doses in eradicating weeds, respectively. A lower value of WPI and higher value of HEI depict satisfactory levels of weed control.

Productive tillers $\left(\mathrm{m}^{-2}\right)$ of wheat were counted from two randomly selected sites $(100 \times 100 \mathrm{~cm})$ from each plot and were averaged. Data on spikelets per spike, number of grains per spike were recorded from 15 randomly selected plants taken from each plot and averaged thereof. A random sample of grains was taken from the output of each plot to record 1000-grains weight after manual counting and weighing on an electric balance. Crop was harvested from an area of $5 \times 1.6 \mathrm{~m}$ from each experimental unit leaving border rows and plot margins, tied into bundles in respective plots, and biological yield of sun dried samples was recorded. Each experimental plot was manually threshed and grain yield was recorded ( $\mathrm{t} \mathrm{ha}^{-1}$ ). The harvest index was calculated as the ratio of grain yield to biological yield and expressed as a percentage.

\section{Statistical and economic analyses}

All the data collected were subject to Fisher's analysis of variance technique (Steel et al., 1997) using the "MSTATC" statistical package. The least significant difference (LSD) test at 0.05 probability was employed 
to compare the difference/s among treatment means. Statistical analysis revealed that year $\times$ treatment effect was non-significant, and hence the mean of $2 \mathrm{yr}$ data are presented and discussed in the results section. Economic and marginal analyses, as well as variable cost based on prevailing market prices of herbicides and wheat, were carried out to evaluate the comparative benefits of each herbicide dose (CIMMYT, 1988).

\section{RESULTS AND DISCUSSION}

\section{Effect of various treatments on weed growth}

Field data revealed that weed flora of experimental plots were comprised of wild oat (Avena fatua L.), canary grass (Phalaris minor Retz.), swine cress (Coronopus didymus [L.] Sm.), broad leaf dock (Rumex dentatus L.), yellow clover (Melilotus indicus [L. All.), fumitory (Fumaria indica [Hausskn.] Pugsley), and blue pimpernel (Anagallis arvensis L.)

Different doses of iodo+mesosulfuron demonstrated a significant effect on total weed density (Table 2), and the difference was more pronounced between narrow and broadleaf weeds at any single dose of herbicide. Herbicides applied at label doses suppressed the density of grasses, broad-leaf, and total weeds by 58, 99, and $95 \%$ respectively, at 45 DAS as compared to the weedy control. Reduction in density at 75 DAS was 93, 95, and $95 \%$ for grasses, broad-leaf, and total weeds, respectively. Iodo+mesosulfuron applied at 50 or $75 \%$ of the label dose furnished a fair level of weed suppression ( $>80 \%)$. Reduced rates of iodo+mesosulfuron were relatively more inhibitory to broad-leaved species as against grasses. When recorded at $75 \mathrm{DAS}$, herbicide at $75 \%$ of label dose suppressed the density of broad-leaved and total weeds comparably $(\mathrm{P} \leq 0.05)$ to its label dose. Interestingly, the suppressive activity of reduced herbicide dose/s in the present studies was maintained at a desirable level of $\geq$ $80 \%$ until 75 DAS.

Application of iodo+mesosulfuron at various doses was equally $(\mathrm{P} \leq 0.05)$ effective in suppressing DM accumulation in weeds until 45 DAS (Table 3). All doses of the herbicide scored $>80 \%$ suppression in dry biomass of grasses and broad-leaved weeds. The same was true for total weed dry weight at 45 and 75 DAS. Label dose of iodo+mesosulfuron recorded as much $(\mathrm{P} \leq 0.05)$ reduction in total weed dry weight as was achieved with its $75 \%$ dose, and was attributed to suppression of both narrow and broad-leaved weeds.

An insight into patterns of individual weed density and dry weight suppression revealed similar trends (Table 4). Reduced herbicide doses were more effective against broad-leaved weeds in terms of both density and dry weight. Reduction in density and dry weight were recorded for broadleaf dock (69-88\% and 98-104\%), swine cress $(82-97 \%$ and $90-98 \%)$, yellow clover (69$93 \%$ and $95-99 \%)$, fumitory (42-92\% and 76-98\%) and blue pimpernel (64-96\% and 79-98\%), respectively. These levels of suppression were similar $(\mathrm{P} \leq 0.05)$ to those recorded with label herbicide doses in most cases (Table 4). Wild oat was knocked out at even $75 \%$ of the label dose, while significant suppression in density (61$73 \%$ ) and dry biomass $(87-93 \%)$ of canary grass over control was recorded at 50 and $75 \%$ of the label dose.

These results suggest that the magnitude of suppression is proportional to the applied herbicide dose and is variable according to the type of weed flora. Broad-leaved

Table 2. Influence of reduced herbicide (Atlantis 3.6WG: iodo+mesosulfuron) doses on weed density in wheat.

\begin{tabular}{|c|c|c|c|c|c|c|}
\hline \multirow[b]{3}{*}{ Treatments } & \multicolumn{6}{|c|}{ Weed density $\left(0.25 \mathrm{~m}^{-2}\right)$} \\
\hline & \multicolumn{3}{|c|}{45 DAS } & \multicolumn{3}{|c|}{75 DAS } \\
\hline & Grasses & Broad-leaved & Total & Grasses & Broad-leaved & Total \\
\hline Weedy control & $7.25 \mathrm{a}$ & $70.75 \mathrm{a}$ & $78.00 \mathrm{a}$ & $12.13 \mathrm{a}$ & $68.50 \mathrm{a}$ & $80.63 \mathrm{a}$ \\
\hline Atlantis $3.6 \mathrm{WG}$ at $3.6 \mathrm{~g}$ a.i. ha-1 (30 DAS) & $4.13 b(-43)$ & $13.00 \mathrm{~b}(-82)$ & $17.13 b(-78)$ & $4.86 \mathrm{~b}(-60)$ & $17.88 \mathrm{~b}(-74)$ & $22.75 b(-72)$ \\
\hline Atlantis $3.6 \mathrm{WG}$ at $7.2 \mathrm{~g}$ a.i. $\mathrm{ha}^{-1}$ (30 DAS) & $3.25 b(-55)$ & $12.50 \mathrm{~b}(-82)$ & $15.75 b(-80)$ & $4.36 \mathrm{~b}(-64)$ & $9.12 \mathrm{c}(-87)$ & $13.50 \mathrm{c}(-83)$ \\
\hline Atlantis $3.6 \mathrm{WG}$ at $10.8 \mathrm{~g}$ a.i. $\mathrm{ha}^{-1}$ (30 DAS) & $3.38 b(-53)$ & $7.13 c(-90)$ & $10.50 \mathrm{c}(-87)$ & $3.13 \mathrm{c}(-74)$ & $1.13 \mathrm{~d}(-98)$ & $4.25 \mathrm{~d}(-95)$ \\
\hline Atlantis $3.6 \mathrm{WG}$ at $14.4 \mathrm{~g}$ a.i. $\mathrm{ha}^{-1}$ (30 DAS) & $3.00 \mathrm{~b}(-58)$ & $0.75 d(-99)$ & $3.75 \mathrm{~d}(-95)$ & $0.86 \mathrm{~d}(-93)$ & $3.50 \mathrm{~d}(-95)$ & $4.38 \mathrm{~d}(-95)$ \\
\hline LSD P $\leq 0.05$ & 1.43 & 4.34 & 4.17 & 1.11 & 4.16 & 4.39 \\
\hline Coefficient of variation, $\%$ & 22.14 & 13.53 & 10.81 & 14.16 & 13.49 & 11.35 \\
\hline
\end{tabular}

DAS: Days after sowing; values given in parenthesis show percent decrease over control; means within a column with different letters differ significantly by LSD at P 0.05 . LSD: least significant difference.

Table 3. Influence of reduced herbicide (Atlantis 3.6WG: iodo+mesosulfuron) doses on weed dry weight in wheat.

\begin{tabular}{|c|c|c|c|c|c|c|}
\hline \multirow[b]{3}{*}{ Treatments } & \multicolumn{6}{|c|}{ 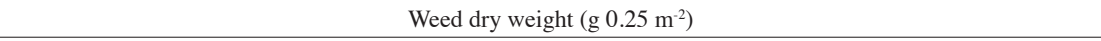 } \\
\hline & \multicolumn{3}{|c|}{45 DAS } & \multicolumn{3}{|c|}{75 DAS } \\
\hline & Grasses & Broad-leaved & Total & Grasses & Broad-leaved & Total \\
\hline Weedy control & $2.07 \mathrm{a}$ & $2.77 \mathrm{a}$ & $4.83 \mathrm{a}$ & $30.00 \mathrm{a}$ & $8.84 \mathrm{a}$ & $38.84 \mathrm{a}$ \\
\hline Atlantis $3.6 \mathrm{WG}$ at $3.6 \mathrm{~g}$ a.i. ha ${ }^{-1}$ (30 DAS) & $0.33 b(-84)$ & $0.43 b(-85)$ & $0.76 b(-84)$ & $5.67 b(-81)$ & $0.94 b(-89)$ & $6.61 b(-83)$ \\
\hline Atlantis $3.6 \mathrm{WG}$ at $7.2 \mathrm{~g}$ a.i. $\mathrm{ha}^{-1}$ (30 DAS) & $0.25 b(-88)$ & $0.36 \mathrm{bc}(-87)$ & $0.61 b(-87)$ & $4.79 b c(-84)$ & $0.54 \mathrm{bc}(-94)$ & $5.34 \mathrm{bc}(-86)$ \\
\hline Atlantis $3.6 \mathrm{WG}$ at $10.8 \mathrm{~g}$ a.i. ha- $\mathrm{ha}^{-1}$ (30 DAS) & $0.43 b(-79)$ & $0.15 b c(-94)$ & $0.58 b(-91)$ & $2.30 \mathrm{~cd}(-91)$ & $0.03 d(-99)$ & $2.33 \mathrm{~cd}(-94)$ \\
\hline Atlantis $3.6 \mathrm{WG}$ at $14.4 \mathrm{~g}$ a.i. $\mathrm{ha}^{-1}$ (30 DAS) & $0.28 b(-87)$ & $0.01 \mathrm{c}(-99)$ & $0.29 b(-94)$ & $0.06 \mathrm{~d}(-99)$ & $0.16 \mathrm{~cd}(-98)$ & $0.22 \mathrm{~d}(-99)$ \\
\hline LSD $P \leq 0.05$ & 0.49 & 0.40 & 0.55 & 3.27 & 0.51 & 3.39 \\
\hline Coefficient of variation, $\%$ & 23.81 & 17.68 & 12.72 & 24.79 & 15.86 & 20.64 \\
\hline
\end{tabular}

DAS: days after sowing; values given in parenthesis show percent decrease over control; means within a column with different letters differ significantly by LSD at P 0.05 . LSD: leas significant difference. 
Table 4. Influence of reduced herbicide (Atlantis 3.6WG: iodo+mesosulfuron) doses on individual weed density $\left(0.25 \mathrm{~m}^{-2}\right)$ and dry weight $\left(\mathrm{g} 0.25 \mathrm{~m}^{-2}\right)$.

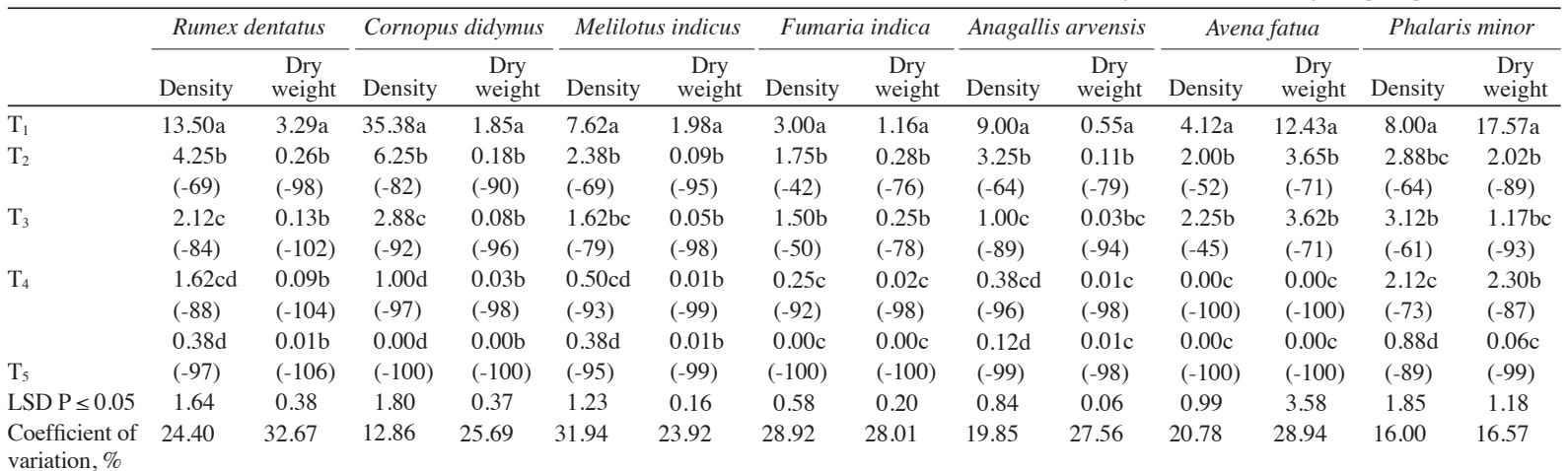

$\mathrm{T}_{1}$ : Weedy control, $\mathrm{T}_{2}$ : Atlantis $3.6 \mathrm{WG}$ at $3.6 \mathrm{~g}$ a.i. ha ${ }^{-1}$ ( $30 \mathrm{~d}$ after sowing DAS), $\mathrm{T}_{3}$ : Atlantis $3.6 \mathrm{WG}$ at $7.2 \mathrm{~g}$ a.i. ha ${ }^{-1}$ (30 DAS), $\mathrm{T}_{4}$ : Atlantis $3.6 \mathrm{WG}$ at $10.8 \mathrm{~g}$ a.i. ha ${ }^{-1}$ (30 DAS), $\mathrm{T}_{5}$ : Atlantis 3.6WG at $14.4 \mathrm{~g}$ a.i. ha ${ }^{-1}(30 \mathrm{DAS})$; values given in parenthesis show percent increase over control; means within a column with different letters differ significantly by LSD at P 0.05 . LSD: least significant difference.

weeds were susceptible to even the lowest herbicide dose, so that their density and dry weight was reduced to $80 \%$ as compared to control. However, for grassy weeds, $75 \%$ of label dose or higher was required to keep weed count to acceptable limits. Reduction in total weed count and biomass was quite promising ( $>70 \%)$, even at the lowest tested doses. Several authors (Boström and Fogelfors, 2002; Walker et al., 2002; Auskalnis and Kadzys, 2006; Barros et al., 2007; Anjum and Bajwa, 2007) reported similar results, concluding that significant weed suppression can be achieved with reduced herbicide rates and providing acceptable weed control during critical periods.

\section{Treatment efficacy}

The WPI was calculated to establish the relative tolerance
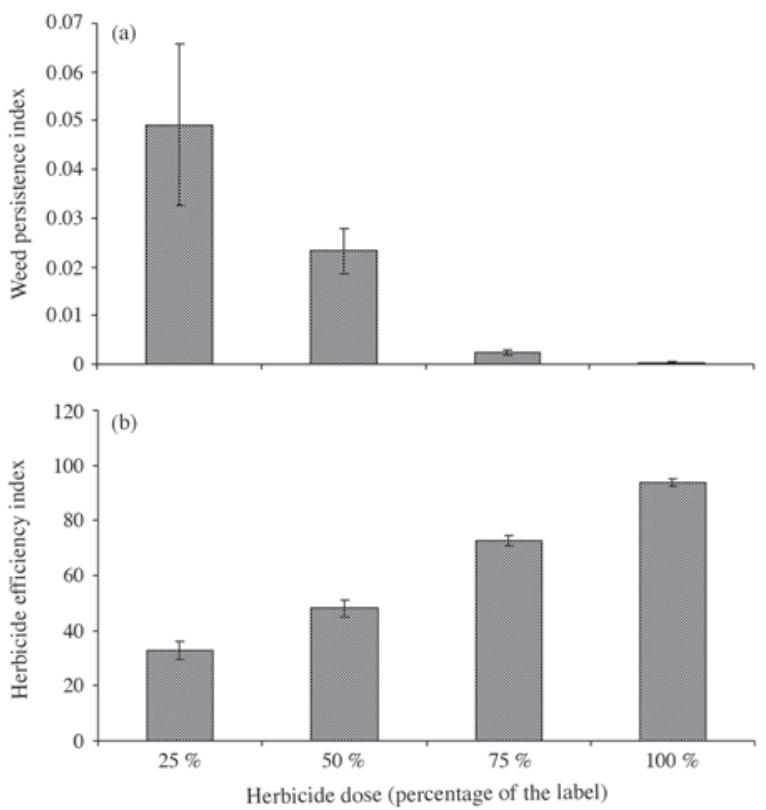

Figure 1. Effect of reduced herbicide doses on (a) weed persistence index and (b) herbicide efficiency index. Vertical bars above mean denote the standard error of four replicates. of weeds to various tested treatments and to gain insights into the efficiency of different doses in retarding weed growth. The lowest WPI was recorded for label dose of iodo+mesosulfuron, indicating that weed density, as well as weed DM production, was well restricted (Figure 1a). A lower WPI value meant a highly effective herbicide dose. The HEI was also calculated to measure the effectiveness of any specific dose of herbicide to eradicate weeds. The label herbicide dose reflected an HEI of 94 and was followed by $75 \%$ herbicide dose, which had an HEI of 73 (Figure 1b). Anjum and Bajwa (2007) also reported that recommended doses of herbicide showed maximum efficiency.

\section{Effect of various treatments on wheat yield and yield components of wheat}

Wheat grain yield was increased in the range of 22-53\% with different doses of iodo+mesosulfuron as compared to control. Iodo+mesosulfuron applied at $75 \%$ of its label dose recorded as high productive tillers, spikelets per spike, grains per spike, 1000-grain weight, grain and biological yield, as was achieved with its label dose (Table 5). Herbicide applied at 25, 50, 75, and $100 \%$ of label dose accounted for 22, 37, 48 and $53 \%$ of yield increases over control, respectively. Wheat yields were negatively associated with weed density and dry weight as denoted, and regression accounted for 89 and $83 \%$ of variation in yield due to density and dry weight of weeds (Figures $2 \mathrm{a}$ and $2 \mathrm{~b}$ ). The increase in grain yield with different herbicide doses may be attributed to reduced weed-crop competition. Such findings are in agreement with those described by Cheema and Khaliq (2000) and Ashiq et al. (2006).

\section{Effect of various treatments on economic and marginal returns}

Application of iodo+mesosulfuron at 25, 50, 75, and $100 \%$ of its label dose resulted in higher net benefits as compared to the control (Table 6). Economic analysis revealed that maximum net benefits (US\$1074.46 ha' ${ }^{-1}$; 
Table 5. Influence of reduced herbicide (Atlantis 3.6WG: iodo+mesosulfuron) doses on yield and yield components of wheat.

\begin{tabular}{|c|c|c|c|c|c|c|c|}
\hline & $\begin{array}{l}\text { Productive } \\
\text { tillers } \mathrm{m}^{-2}\end{array}$ & $\begin{array}{l}\text { Spikelets } \\
\text { per spike }\end{array}$ & $\begin{array}{c}\text { Grains } \\
\text { per spike }\end{array}$ & $\begin{array}{c}\text { 1000-grain } \\
\text { weight }\end{array}$ & Grain yield & $\begin{array}{l}\text { Biological } \\
\text { yield }\end{array}$ & $\begin{array}{c}\text { Harvest } \\
\text { index }\end{array}$ \\
\hline & & & & $\mathrm{G}$ & 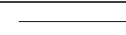 & - & $\%$ \\
\hline $\mathrm{T}_{1}$ & $265.50 \mathrm{~d}$ & $14.20 \mathrm{~b}$ & $31.43 \mathrm{c}$ & $41.48 b$ & $2.54 \mathrm{c}$ & $9.71 b$ & $26.19 b$ \\
\hline $\mathrm{T}_{2}$ & $\begin{array}{c}298.80 \mathrm{~cd} \\
\quad(13)\end{array}$ & $\begin{array}{c}14.70 \mathrm{~b} \\
(4)\end{array}$ & $\begin{array}{c}35.82 b c \\
(14)\end{array}$ & $\begin{array}{c}46.83 \mathrm{a} \\
(13)\end{array}$ & $\begin{array}{c}3.12 b \\
(22)\end{array}$ & $\begin{array}{c}10.62 \mathrm{ab} \\
(9)\end{array}$ & $\begin{array}{c}29.39 \mathrm{ab} \\
(12)\end{array}$ \\
\hline $\mathrm{T}_{3}$ & $\begin{array}{c}316.5 b c \\
(19)\end{array}$ & $\begin{array}{c}14.70 b \\
(4)\end{array}$ & $\begin{array}{c}38.78 \mathrm{ab} \\
(23)\end{array}$ & $\begin{array}{c}46.79 a \\
(13)\end{array}$ & $\begin{array}{l}3.49 \mathrm{ab} \\
(37)\end{array}$ & $\begin{array}{c}10.63 \mathrm{ab} \\
(9)\end{array}$ & $\begin{array}{c}32.83 \mathrm{a} \\
(25)\end{array}$ \\
\hline $\mathrm{T}_{4}$ & $\begin{array}{c}337.50 \mathrm{ab} \\
(27)\end{array}$ & $\begin{array}{c}15.50 \mathrm{a} \\
(9)\end{array}$ & $\begin{array}{c}41.00 \mathrm{a} \\
(30)\end{array}$ & $\begin{array}{c}48.93 \mathrm{a} \\
(18)\end{array}$ & $\begin{array}{c}3.77 \mathrm{a} \\
(48)\end{array}$ & $\begin{array}{c}11.46 \mathrm{a} \\
(18)\end{array}$ & $\begin{array}{c}32.89 \mathrm{a} \\
(26)\end{array}$ \\
\hline $\mathrm{T}_{5}$ & $\begin{array}{c}354.30 \mathrm{a} \\
(33)\end{array}$ & $\begin{array}{c}15.80 \mathrm{a} \\
(11)\end{array}$ & $\begin{array}{c}42.75 a \\
(36)\end{array}$ & $\begin{array}{c}49.16 \mathrm{a} \\
(19)\end{array}$ & $\begin{array}{c}3.91 \mathrm{a} \\
(53)\end{array}$ & $\begin{array}{c}11.88 \mathrm{a} \\
(22)\end{array}$ & $\begin{array}{c}32.91 \mathrm{a} \\
(26)\end{array}$ \\
\hline LSD & 33.99 & 0.67 & 4.64 & 2.69 & 0.43 & 1.59 & 4.62 \\
\hline Coefficient of variation, $\%$ & 7.02 & 2.94 & 7.93 & 3.75 & 8.34 & 9.55 & 9.66 \\
\hline
\end{tabular}

$\mathrm{T}_{1}$ : Weedy control, $\mathrm{T}_{2}$ : Atlantis $3.6 \mathrm{WG}$ at $3.6 \mathrm{~g}$ a.i. ha ${ }^{-1}$ (30 d after sowing DAS), $\mathrm{T}_{3}$ : Atlantis $3.6 \mathrm{WG}$ at $7.2 \mathrm{~g}$ a.i. ha ${ }^{-1}$ (30 DAS), $\mathrm{T}_{4}$ : Atlantis $3.6 \mathrm{WG}$ at $10.8 \mathrm{~g}$ a.i. ha ${ }^{-1}$ (30 DAS), $\mathrm{T}_{5}$ : Atlantis 3.6WG at $14.4 \mathrm{~g}$ a.i. ha ${ }^{-1}$ (30 DAS); values given in parenthesis show percent increase over control; means within a column with different letters differ significantly by LSD at P 0.05. LSD: least significant difference.
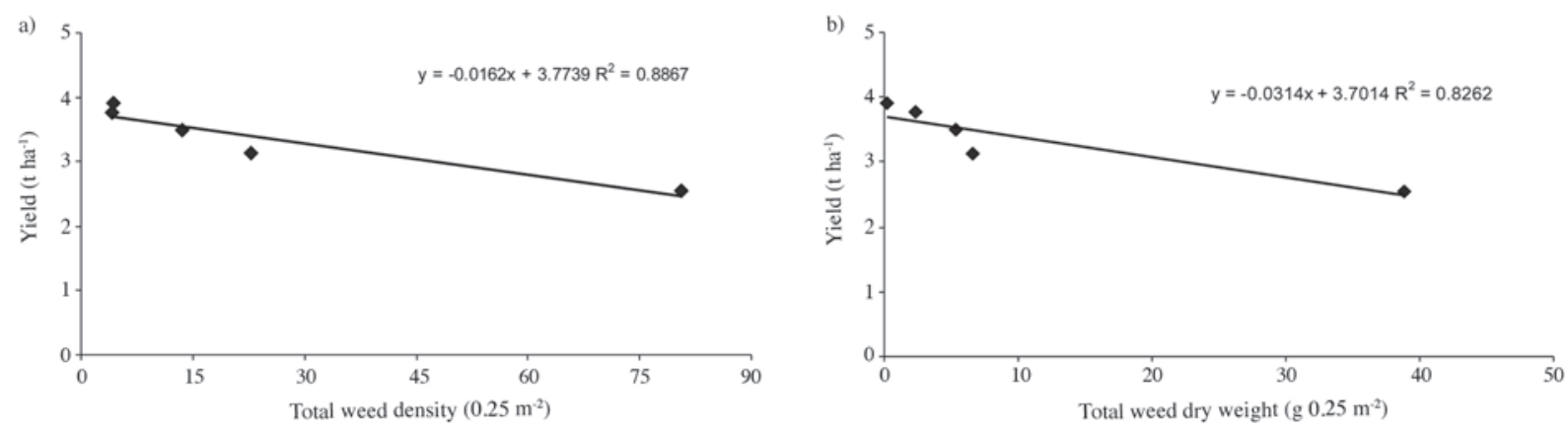

Figure 2. Relationship between total weed density (a), total weed dry weight (b) with wheat grain yield.

Table 6. Economic analysis of reduced herbicide doses in wheat.

\begin{tabular}{|c|c|c|c|c|c|c|}
\hline Treatments & $\mathrm{T}_{1}$ & $\mathrm{~T}_{2}$ & $\mathrm{~T}_{3}$ & $\mathrm{~T}_{4}$ & $\mathrm{~T}_{5}$ & Remarks \\
\hline Total grain yield & 2.65 & 3.12 & 3.50 & 3.77 & 3.92 & $\mathrm{t} \mathrm{ha}^{-1}$ \\
\hline Gross income & 741.64 & 872.85 & 979.16 & 1054.69 & 1096.65 & US $\$ 279.76 \mathrm{t}^{-1}$ \\
\hline Cost of herbicide & - & 4.83 & 9.67 & 14.5 & 19.34 & Atlantis 3.6WG (US\$ $19.34 / 400 \mathrm{~g} \mathrm{ha}^{-1}$ ) \\
\hline Spray rent & - & 1.07 & 1.07 & 1.07 & 1.07 & US\$1.07 spray $^{-1}$ \\
\hline Spray application & - & 1.78 & 1.78 & 1.78 & 1.78 & US\$1.78 man $^{-1}$ (one man $\mathrm{d}^{-1} \mathrm{ha}^{-1}$ ) \\
\hline Costs that vary & 0 & 7.68 & 12.52 & 17.35 & 22.19 & US\$ ha-1 \\
\hline Net benefit & 741.64 & 865.17 & 966.64 & 1037.34 & 1074.46 & US\$ ha-1 \\
\hline
\end{tabular}

$\mathrm{T}_{1}$ : Weedy control, $\mathrm{T}_{2}$ : Atlantis $3.6 \mathrm{WG}$ at $3.6 \mathrm{~g}$ a.i. ha ${ }^{-1}$ (30 d after sowing DAS), $\mathrm{T}_{3}$ : Atlantis $3.6 \mathrm{WG}$ at $7.2 \mathrm{~g}$ a.i. ha ${ }^{-1}$ (30 DAS), $\mathrm{T}_{4}$ : Atlantis $3.6 \mathrm{WG}$ at $10.8 \mathrm{~g}$ a.i. ha ${ }^{-1}$ (30 DAS), $\mathrm{T}_{5}$ : Atlantis 3.6WG at $14.4 \mathrm{~g}$ a.i. ha ${ }^{-1}$ (30 DAS). 1 US\$ $=$ Rs. 84 .

1US\$ = Rs. 84) were obtained with use of the label dose of herbicide. Application of $75 \%$ of label dose yielded net benefit of US\$1037.34 ha ${ }^{-1}$. Marginal analyses were carried out further to provide insights into relative net returns with increased input costs involved in varying herbicide doses (Table 7). A reduced (50\%) dose of iodo+mesosulfuron exhibited the highest $(2168.16 \%)$ marginal rate of return (MRR) and was followed by MRR of $1608.46 \%$ recorded for $25 \%$ of the label herbicide dose. Despite its efficacy, the label herbicide dose exhibited an MRR of $766.94 \%$. Relatively higher net returns associated with label herbicide doses were also reported by Barroso et al. (2009).

Table 7. Marginal analysis of reduced herbicide (Atlantis 3.6WG: iodo+mesosulfuron) doses in wheat.

\begin{tabular}{|c|c|c|c|c|c|}
\hline Treatments & $\begin{array}{c}\text { Cost that } \\
\text { vary }\end{array}$ & $\begin{array}{c}\text { Net } \\
\text { benefit }\end{array}$ & $\begin{array}{l}\text { Change } \\
\text { in cost }\end{array}$ & $\begin{array}{l}\text { Change in } \\
\text { net benefit }\end{array}$ & $\begin{array}{c}\text { Marginal rate } \\
\text { of return }\end{array}$ \\
\hline & \multicolumn{4}{|c|}{ US\$ ha ${ }^{-1}$} & $\%$ \\
\hline Weedy control & 0 & 741.64 & - & - & - \\
\hline Atlantis $3.6 \mathrm{WG}$ at $3.6 \mathrm{~g}$ a.i. $\mathrm{ha}^{-1}$ (30 DAS) & 7.68 & 865.17 & 7.68 & 123.53 & 1608.46 \\
\hline Atlantis $3.6 \mathrm{WG}$ at $7.2 \mathrm{~g}$ a.i. $\mathrm{ha}^{-1}(30 \mathrm{DAS})$ & 12.52 & 966.64 & 4.68 & 101.47 & 2168.16 \\
\hline Atlantis $3.6 \mathrm{WG}$ at $10.8 \mathrm{~g}$ a.i. $\mathrm{ha}^{-1}$ (30 DAS) & 17.35 & 1037.34 & 4.83 & 70.7 & 1463.76 \\
\hline Atlantis $3.6 \mathrm{WG}$ at $14.4 \mathrm{~g}$ a.i. $\mathrm{ha}^{-1}$ (30 DAS) & 22.19 & 1074.46 & 4.84 & 37.12 & 766.94 \\
\hline
\end{tabular}

DAS: days after sowing; Variable cost is the cost of purchase of inputs, labor and machinery per hectare that vary between the experimental treatments; net benefit exhibits the gross income less variable cost; marginal rate of return is the additional net benefits associated per unit increase in variable cost for a specific dose of herbicide, and expressed as $\%$. 1 US $\$=$ Rs. 84 . 


\section{CONCLUSION}

Results of 2-yr experiments revealed that a fairly acceptable level of weed suppression in wheat fields was achieved with lower doses of iodo+mesosulfuron that were comparable to results with its label dose. It can be used as a cost effective, economical and environmentally friendly approach to minimize weed pressure. Similar studies need to be carried out under varying soil and environmental conditions in various field crops, and for herbicides with different modes of action.

\section{Dosis reducidas de herbicida sulfonilurea para control de malezas en trigo en Punjab, Pakistán.} Reducción del uso de herbicidas sin comprometer el rendimiento puede dar lugar a menos riesgos ambientales y disminución de los costos de producción. Los ensayos de campo se llevaron a cabo para evaluar la eficacia de dosis reducidas $(25,50$ y $75 \%$ de la dosis de etiqueta) de un herbicida sulfonilurea [Atlantis3.6WG (yodo + mesosulfurón)] de postemergencia para controlar las malezas en trigo (Triticum aestivum L.) en campos de Punjab, Pakistán. Las dosis por debajo de la recomendada en la etiqueta eran muy eficaces en la supresión de la densidad total de malezas (72-95\%) y biomasa (83-94\%), y rendimiento en grano de trigo se incrementó en un 22 a $48 \%$ por sobre el control, mientras que la dosis de etiqueta de yodo + mesosulfurón mejoró el rendimiento en un 53\%. Yodo+mesosulfurón a 25 y $50 \%$ de la dosis de etiqueta inhibe las malezas gramíneas por 43 a $64 \%$, aunque su biomasa fue suprimida $>80 \%$ respecto al control. Los rendimientos de trigo para las dosis de herbicidas reducidas (50 y 75\%) no fueron diferentes de la dosis de etiqueta. El análisis económico reveló que la tasa máxima de retorno marginal se registró con el $50 \%$ de la dosis de etiqueta del herbicida, y fue seguido por $25 \%$ de la dosis de etiqueta. Dosis reducidas de herbicidas pueden ser una herramienta eficaz en la reducción del uso de herbicidas y disminución de los costos de producción en los campos de trigo sin comprometer los rendimientos.

Palabras clave: dosis reducidas de herbicidas, supresión de malezas, eficiencia, rendimiento de trigo.

\section{LITERATURE CITED}

Anjum, T., and R. Bajwa. 2007. The effect of sunflower leaf extracts on Chenopodium album in wheat fields in Pakistan. Crop Protection 26:1390-1394.

Ashiq, M., N. Muhammad, and N. Ahmad. 2006. Comparative efficacy of different herbicides to control grassy weeds in wheat. Pakistan Journal of Weed Science Research 12:157-161.

Auskalnis, A., and A. Kadzys. 2006. Effect of timing and dosage in herbicide application on weed biomass in spring wheat. Agronomy Research 4:133-136.

Barros, J.F.C., G. Basch, and M. Carvalho. 2005. Effect of reduced doses of a post-emergence graminicide mixture to control Lolium rigidum $\mathrm{G}$. in winter wheat under direct drilling in Mediterranean environment. Crop Protection 24:880-887.
Barros, J.F.C., G. Basch, and M. Carvalho. 2007. Effect of reduced doses of a post-emergence herbicide to control grass and broadleaved weeds in no-till wheat under Mediterranean conditions. Crop Protection 26:1538-1545.

Barroso, J., D. Ruiz, C. Escribano, L. Barrios, and C. FernandezQuintanilla. 2009. Comparison of three chemical control strategies for Avena sterlis ssp. ludoviciana. Crop Protection 28:393-400

Barton, D.L., D.C. Thill, and B. Shafi. 1992. Integrated wild oat (Avena fatua) management affects spring barley (Hordeum vulgare) yield and economics. Weed Technology 6:129-135.

Belles, D.S., D.C. Thill, and B. Shafi. 2000. PP-604 rate and Avena fatua density effects on seed production and viability in Hordeum vulgare. Weed Science 48:378-384.

Boström, U., and H. Fogelfors. 2002. Response of weeds and crop yield to herbicide dose decision-support guidelines. Weed Science 50:186-195.

Cheema, Z.A., and A. Khaliq. 2000. Use of sorghum allelopathic properties to control weeds in irrigated wheat in a semi arid region of Punjab. Agriculture Ecosystems \& Environment 79:105-112.

CIMMYT. 1988. From agronomic data to farmer recommendations: An economics training manual. Completely revised edition. Centro Internacional de Mejoramiento de Maíz y Trigo (CIMMYT), Mexico D.F., Mexico.

Gupta, O.P. 2004. Modern weed management. $2^{\text {nd }}$ ed. p. 18-23. Agrobios, Jodhpur, India.

Heap, I. 2007. The International Survey of Herbicide Resistant Weeds [Online] 02 April 2007. Herbicide Resistance Action Committee (HRAC), North American Herbicide Resistance Action Committee (NAHRAC), and Weed Science Society of America (WSSA), Corvallis, Oregon, USA. Available at http:// www.weedscience.com (accessed 2 February 2007).

Holm, F.A., K.J. Kirkland, and F.C. Stevenson. 2000. Defining optimum herbicide rates and timing for wild oat control in spring wheat. Weed Technology 14:167-175.

Kahramanoglu, I., and F.N. Uygur. 2010. The effects of reduced doses and application timing of metribuzin on redroot pigweed (Amaranthus retroflexus L.) and wild mustard (Sinapis arvensis L.). Turkish Journal of Agriculture and Forestry 34:467-474.

Khan, M.S. 1998. Pakistan crop protection market. PAPA Bulletin 9:7-9.

Khan, M., and N. Haq. 2002. Wheat crop yield loss assessment due to weeds. Sarhad Journal of Agriculture 18:449-453.

Rao, V.S. 2000. Principles of weed sciences. $2^{\text {nd }}$ ed. Oxford and IBH Publishing Co. Pvt. Ltd., New Delhi, India.

Steckel, G.J., L.M. Wax, F.W. Simmons, and W.H. Phillips II. 1997. Glufosinate efficacy on annual weeds is influenced by rate and growth stage. Weed Technology 11:484-488.

Steel, R.G.D., J.H. Torrie, and D. Dickey. 1997. Principles and procedures of statistics: A biometrical approach. $3^{\text {rd }}$ ed. p. 172177. McGraw Hill Book, New York, USA.

Talgre, L., E. Lauringson, and M. Koppel. 2008. Effect of reduced herbicide dosages on weed infestation in spring barley. Zemdirbyste-Agriculture 95:194-201.

Walia, U.S. 2003. Principles of weed research experiments. p. 334350. In: Weed Management, Kalyani Publishers, New Delhi, India.

Walker, S.R., R.W. Medd, G.R. Robinson, and B.R. Cullis. 2002. Improved management of Avena ludoviciana and Phalaris paradoxa with more densely sown wheat and less herbicide. Weed Research 42:257-270.

Zhang, J., S.E. Weaver, and A.S. Hamill. 2000. Risks and reliability of using herbicides at below-labeled rates. Weed Technology $14: 106-115$ 